Man and Nature

MAN AND NATURE

L'homme et la nature

\title{
Dante's Concept of Nobility and the Eighteenth-Century Tuscan Aristocracy: An Unknown Study of the Convivio
}

\section{Domenico Pietropaolo}

Volume 5, 1986

URI : https://id.erudit.org/iderudit/1011858ar

DOI : https://doi.org/10.7202/1011858ar

Aller au sommaire du numéro

Éditeur(s)

Canadian Society for Eighteenth-Century Studies / Société canadienne d'étude du dix-huitième siècle

ISSN

0824-3298 (imprimé)

1927-8810 (numérique)

Découvrir la revue

Citer cet article

Pietropaolo, D. (1986). Dante's Concept of Nobility and the Eighteenth-Century Tuscan Aristocracy: An Unknown Study of the Convivio. Man and Nature /

L'homme et la nature, 5, 141-152. https://doi.org/10.7202/1011858ar

Copyright (c) Canadian Society for Eighteenth-Century Studies / Société canadienne d'étude du dix-huitième siècle, 1986
Ce document est protégé par la loi sur le droit d'auteur. L'utilisation des services d'Érudit (y compris la reproduction) est assujettie à sa politique d'utilisation que vous pouvez consulter en ligne.

https://apropos.erudit.org/fr/usagers/politique-dutilisation/ 


\section{Dante's Concept of Nobility and the Eighteenth-Century Tuscan Aristocracy: An Unknown Study of the Convivio}

In 1732 there appeared in Lucca a brief work by one Angelo Poggesi on the fourth book of Dante's Convivio. ${ }^{1}$ It analysed Dante's canzone in the light of modern culture and attempted to force the conclusion that it contained the only scientifically valid and politically desirable concept of nobility available to his generation. It was meant to be a very controversial pamphlet but it fell miserably short of its intent. The author's main concern was not strictly academic, his prose was too garbled, and his manner of presentation too desultory for him to meet the professional standards of the time. His more famous contemporaries, those who provided later researchers with reasons to start investigating the methods and ideas of early eighteenth-century criticism, did not take note of it, and it has consequently remained buried in total obscurity. This fact now makes the recovery of Poggesi's work especially significant, since it allows us to come into contact for the first time with an undercurrent of critical thought which has systematically escaped the notice of historians of criticism and eighteenth-century scholars. In the present paper, Poggesi's chief arguments are analysed and appraised against the background of the Dante studies of the early eighteenth century, the contemporary scientific debate on hereditism and genetic continuity, and the Tuscan policy on academic freeedom during the reign of the last Medici grand dukes.

Despite the indifference with which his work was received, Poggesi's unconditional admiration for Dante and the critical strategy that he 
adopts are both deeply rooted in the Tuscan philological tradition, which endowed all of its new adherents with the legacy of an enduring literary cult of the poet and which charged Tuscan scholarship with the responsibility of its tutelage. Following the example of established critics who worked within this tradition, ${ }^{2}$ Poggesi unearths an earlier denigrator of Dante, dislodges his incriminatory arguments, and presents his own view of the matter as a logical necessity. But by choosing to argue for the philosophical validity and social significance of the Convivio rather than the aesthetic dignity of the Divine Comedy, he steps over the orientative boundaries of the critical tradition and implicitly accepts the task of demonstrating the potential relevance of Dante to life outside Academia.

The mainstream of Tuscan literary scholarship did not then readily venture into areas which were not explicitly sanctioned by the received tradition as suitable topics of investigation, and in general refrained from bringing into a critical discussion its own potentially controversial, extra-academic affiliations. Poggesi's conscious withdrawal from the critical establishment, the parameters of which were criteria of professional competence as well as guarantees of success, constitutes for us his principal claim to belated recognition in the history of Dante criticism after his protracted inconspicuousness. Poggesi's work first of all invalidates the commonly held view that, although the Convivio had been incidentally mentioned by the critics of the sixteenth century, it did not become the object of specific and systematic examination until the last decades of the eighteenth century. ${ }^{3}$ Indeed, the fact that it is structured as a refutation of someone else's ideas is evidence that there had been an even earlier study of the Convivio which, like Poggesi's pamphlet, has hitherto not come to the attention of modern scholars, although one could assume knowledge of it in the early Settecento. This means that the Convivio and what critical literature was available on it were then more widely known than is generally believed.

It is certainly significant that Poggesi, in an age when everyone with some education belonged to at least one academy wherein he assumed a literary pseudonym, felt confident that his readers would recognise the identity of his chosen adversary without being told his real name. Poggesi refers to him as Simon Faustumo and warns his readers that this name at once reveals and conceals the identity of the person in question. Simon Faustumo is in fact a perfect anagram of Faustino Summo, a late Renaissance critic from Padua who, in 1590, published a work entitled Della nobiltà, which is an attack on Dante's concept of nobility. ${ }^{4}$

Predictably enough for a Paduan scholar of the time, especially one who had been a disciple of Giason Denores, Summo's starting point is Aristotle, whose definition of nobility, although not mentioned in the 
Convivio, does not differ from that attributed by Dante to Frederick II and immediately rejected by him. As Dante had begun by demonstrating that the emperor could exercise no legitimate supremacy in a philosophical question, so Poggesi strikes his first and major blow at his opponent by proscribing the authority of Aristotle. For the ancient philosopher nobility was excellence of stock, which resulted from the combination of virtue and wealth inherited through a long genealogical history. ${ }^{5}$ For Poggesi and for Dante it is a kind of internal perfection that has nothing to do with family wealth. That there is nothing perfect or ennobling about money, Poggesi claims, is clear from the fact that oftener than not it is the cause and instrument of social evil and a thing that can change good men into 'vile, imperfect, fearful, solicitous, restless and insatiable' beings. ${ }^{6}$ By showing how the essentially imperfect nature of wealth cannot be the origin of the necessarily perfect nature of nobility, Dante - Poggesi concludes - proved beyond doubt that riches are not a measure of nobility. Similarly irrefutable seems to Poggesi Dante's contention that nobility is independent of lineage and time, which cannot alter its state or give rise to its existence. Dante had revealed the absurdity of the idea that a noble child cannot be born of ignoble parents, since it would ultimately force us to accept the heretical conclusion that mankind does not derive only from Adam but from two autonomous forefathers, one noble and the other not. Nor had he admitted that children of ignoble parents could attain nobility when their parents' baseness had fallen into oblivion, since we would be forced to regard imperfection (of memory) as the generating cause of nobility in human beings, whereas perfection (of attributes) would still be the determining factor of nobility in all other species. Poggesi fully agrees with Dante that the obtuseness of those who maintain this position deserves to be chastised not only with pungent words but also with a sharp knife. ${ }^{7}$

Yet Summo had chosen to defend precisely this evolutionary thesis and had risen against Dante with formidable antagonism. As gold, he had shrewdly argued, is made progressively purer by a smith who regards each extract as raw material and repeats the smelting process several times, so too an impure seminal virtue (virtú seminale), tainted in the progenitors with some disposition to ignoble acts, becomes increasingly more noble as it is transmitted from father to son - the more ancient the lineage, the nobler the stock: true nobility is therefore 'an ancient virtue in a family stock. ${ }^{\prime}$ The relevance of this conclusion to the eighteenth century - 'a conceited century,' as we are told - is made explicit by Poggesi when he cynically reminds his readers that money and a long family history, which were the distinguishing features of the aristocracy, were still regarded as sufficient proof of true nobility. 
Summo's argument is ultimately based on Aristotle's theory of generation and hereditism, according to which semen is endowed with the power (i.e., virtú seminale) to impart form or soul to appropriate substances in the menstrual fluid, causing in that manner the actualisation of the new being which is otherwise only potentially present in the female. ${ }^{9}$ This principle, as filtered through St. Thomas Aquinas into the culture of the late Middle Ages, became a determining factor in the development of juristic theories of inheritance and dynastic continuity, by means of the widely accepted legal fictio of the identity of father and son. ${ }^{10}$ It is easy to see how such ideas could yield a scientific justification of the perpetual inheritance of wealth and privilege by the aristocracy as the only embodiment of true nobility.

Poggesi reacts to Summo's position by undermining its scientific foundation: There is no seminal virtue that may be passed on to successive generations, since semen alone, and not dispositions and attitudes, is involved in the reproductive process. Nobility is therefore something that individuals cannot inherit from their parents nor bequeath to their children. But even if such a seminal virtue existed, it could not lose any of its alleged imperfection with the passage of time, since there is no external force, comparable to the smith's flame, that is brought to bear upon it. Time by itself would alter neither the purity of man's presumed seminal virtue nor that of gold.

In order to appreciate Poggesi's counter argument and to see how it in reality refers to the aristocracy of his time, it is necessary to recall the contemporary debate on the hereditary transmission of somatic and spiritual characteristics. The biologists of Poggesi's generation were divided into two groups: the epigenetists, who believed that the embryo is formed, a little at a time, as if by the addition of parts, after the coital union; and the preformationists, who believed that the omaccino, as they called the embryo, was already completely formed in the semen or in the ovum prior to the sexual act, which simply initiated the process of development. ${ }^{11}$ Poggesi does not specify what, in his view, is the role of the semen, but it is clear that by refuting Summo's Aristotelian physiology he is really taking issue with the semen-preformationists of his day, who held that the semen-omaccino necessarily possesses the most significant traits of the father, including such non-physical features as instincts and virtues, the presence of which would thus be assured in the child. In rejecting the preformationists' theory, Poggesi is in effect dismissing the only contemporary scientific basis for a legal justification of the privileges of the Tuscan aristocracy. Dante, who had been denigrated by Summo on behalf of ruling class principles, was now vin- 
dicated by Poggesi in a rebellion against them and hence instrumentalised as a vehicle of thought and a means of political criticism.

An important observation that can be made about Poggesi's views is that they stem directly from the social and cultural conditions of Tuscany under the last Medici grand duke, Giangastone. A few years earlier, before the death of Cosimo III, Poggesi's defence of the Convivio against Faustino Summo would not have been possible. Summo's ultimate authority was Aristotle, and Cosimo III, under the influence of priests and theologians who wanted to keep atomism out of Tuscany, had decreed in 1691 that henceforth 'the professors of his University of Pisa may not lecture on Democritean philosophy, that is of the atoms, nor teach it in public or in private, in written or oral form, but only on Aristotelian philosophy. ${ }^{12}$ Aristotle had been legislated as the utmost philosophical arbiter, and the faculty of Tuscany's most important academic institution was forbidden to discredit his authority. On the other hand, Democritus, Epicurus, Lucretius and Gassendi had been debarred from Tuscan culture, lest they should draw unsuspecting good Christians into the error of materialism. By 1731, a year before Poggesi published his work, Giangastone had had the good sense to abrogate his father's law and to restore academic freedom to that famous university. In fact that year Giangastone granted a member of the faculty the right to teach whatever books he considered appropriate and to disregard the traditional texts if he so chose, a privilege extended to the entire teaching staff a few years later by Gaspare Cerati, whom Giangastone appointed rector of the university in $1733 .{ }^{13}$ Poggesi, himself a Pisan, composed his defence of Dante at a time when, from an academic point of view, life must have been very exciting and optimistic. The official Tuscan culture had been granted permission to seek rejuvenation; old dogmas could finally be tested, and rejected if found unsatisfactory.

When Poggesi examined Aristotle's view of nobility, he found that it did not pass the test of time; it was not universally valid because it did not reflect the current situation. Poggesi could discern no nobility in those that had inherited ancient riches. He saw that most of the aristocratic class of Tuscany comprised a false nobility, fully conceited and able to display none of the virtues that render men truly noble individuals. He may also have seen that even politically their nobility was false, for this class of prominent citizens no longer played a significant role in the administration of the country. If Cosimo III had forced the aristocrats of Tuscany to simulate noble virtues, Giangastone had given their true nature the freedom to bloom into complete decadence, often deriding them and preferring to keep company with hired ribalds and prostitutes. 
On the other hand, a vantage point based on the principles given in the Convivio seemed to Poggesi more universally valid. Dante's view of nobility as a personal form of excellence had not failed the test of time. In authors that preceded him as well as in writers of later generations Poggesi could find more attestations of the validity of Dante's principles than statements to the contrary. ${ }^{14}$ But more important than the literary evidence that might be adduced in support of Dante's position with the strength of numbers was for Poggesi the fact that the thesis of the Convivio does not lead to the conclusion that the eighteenth-century Tuscan aristocrats were a class of noble men and women. It would, in fact, force the opposite conclusion. Dante's admonition to the unworthy aristocracy of his day to the effect that an illustrious stock is not proof of nobility should be cited, according to Poggesi, to the aristocrats of the eighteenth century, who defend their presumed nobility on the grounds of some illustrious family background. ${ }^{15}$

The claim that is being made in this context, where Dante is essentially regarded as a potential teacher of moral and political wisdom, is that the Convivio is relevant to contemporary life and not only to contemporary philosophy and literary criticism. This is a new note in the Tuscan Dante studies of this period, and its significance needs to be duly stressed. An important characteristic of most other Dante criticism is that it naturally tends to relegate the poet to the academic world of books and libraries, wherein he can be defended, censured, imitated, studied, praised or even hailed as the idol of a literary cult. With Poggesi, Dante - at least as far as the Convivio is concerned - crosses these academic boundaries and becomes a magister vitae. Reading Dante is a profitable academic exercise because it prepares students to become better literati; first and foremost, however, it is an edifying experience because it reveals how one may become a more worthy human being and live as a better member of society.

When Poggesi faces the question of what exactly is meant by nobility in the Convivio, he candidly confesses that he found the text almost impenetrable on that point and admits that in his interpretation there is some unavoidable uncertainty. The main steps of his argument are the following. A seed of nobility is injected by God into the body of an unborn child 'in the womb of an honest woman.' ${ }^{16}$ The potential power of this seed may be curbed by the child's body if his constitution is imperfect. After birth, when the child is able to exercise his will, his latent nobility will flourish in proportion to the righteousness of his volitions and actions. This seed of nobility is 'none other than the living light of intelligence. ${ }^{\prime 17}$

This interpretation of the Dantesque concept of nobility presents 
several points of interest. First of all, although in the rest of his lecture Poggesi everywhere upholds the principle that nobility is a question of personal merit rather than of social class, here he unintentionally reveals a prejudice, and brings into play, as a determining factor, the position occupied by the individual in the social hierarchy. The divine seed of nobility is infused only in the womb of honest women; the children of prostitutes and illegitimate children are automatically excluded from this caste. There is, of course, very little to be surprised at in the fact that a Tuscan of this period - especially one who lived for many years under Cosimo III - has such a preconception, since adultery and prostitution were then considered the most abject vices of society. ${ }^{18}$ It is, however, noteworthy that the author should let that prejudice trickle into his lecture, wherein the concept is indirectly attributed to Dante, because it shows that he has misread the text. It furthermore makes his position much less innovative than it might have been. While on the one hand Poggesi argues against the automatic restriction of nobility to one particular social class, on the other he altogether denies one group the right to become noble even through personal merit.

In Convivio IV, xx, Dante calls nobility a divine 'seme di felicitade'and explains that biologically it first comes into being when the body is infused with the rational soul, and that theologically it is identical with the sanctifying grace bestowed by the Holy Spirit upon those who are worthy of it. Poggesi does not mention any of this. Instead, true to the spirit of the eighteenth century, he identifies the Dantesque source of temporal happiness with intelligence or the ability to reason, a conclusion that is hardly surprising in the age that idolatrised that faculty of man. It is nevertheless a very interesting interpretation, for while it renders even more puzzling the author's prejudice against prostitutes, it allows him to explain from a psycho-physiological point of view Dante's statement that the degree of potential nobility that comes from God depends also on how fit the recepient's body is to receive it. Poggesi does this by refuting the Cartesian principle that the soul is a pure spirit and hence that thinking, which is an activity of the soul, is a spiritual operation. And in order to accomplish this philosophical task Poggesi calls on the authority of none other than Pierre Gassendi, a champion of anti-Cartesianism as well as of anti-Aristotelianism and the reviver and defender of that philosophy of atomism which had been outlawed by Cosimo III and later restored to legitimacy by Giangastone, who had even allowed the publication of his Opera omnia in $1727 .{ }^{19}$ Drawing strength of argument from Gassendi, Poggesi states that the soul is dispersed throughout the entire body, and that its activity of thinking may be affected by the relative excellence of the matter in which the soul is harboured.20 
In Poggesi's interpretation, therefore, the Dantesque ennobling 'seme di felicitade' is intelligence, present in all men in degrees varying with their relative proximity to a perfect body, developed in proportion to their cultivation of it, and productive of temporal happiness in accordance with their ability to let it guide their will to a morally correct form of behaviour. Intelligence, and nothing else, is the source of the moral virtues that 'give us earthly happiness, although we were placed in this deep vale of miseries and tears. ${ }^{21}$ In the final analysis Poggesi's reading of the Convivio becomes this urgent suggestion that he, in his disillusionment and pessimism, makes to his fellow men: that they place in their own intelligence their hopes of ever being happy, for only through the development and correct use of that faculty can they obtain relief from affliction; and that they look up to human intelligence with the greatest possible deference, for it is from that source alone - and not from riches or from a long genealogical history - that man derives whatever nobility he has. An aristocracy of morally and intellectually exalted minds, and not a privileged class of citizens, is the real collective embodiment of nobility.

From the point of view of literary criticism Poggesi's procedure leaves some things to be desired. In the first place he makes no reference to Dante's treatment of the theme of nobility in his other works. ${ }^{22}$ In the second place, he does not seek in Dante, but in a seventeenth-century philosopher, a definition of the soul in order to carry out his analysis. Having found a definition that suits his line of thinking, he does not ask whether Dante would endorse it, but rather superimposes it readily on the text. The fact that Poggesi did not even pose these problems in his study makes him a less reliable Dante scholar than he might have been otherwise.

This, however, does not diminish the significance of his study, which is devoted to explaining the fourth treatise of the Convivio as a work of great contemporary relevance rather than simply of academic interest. In fact, the allegiance that is thereby established between Poggesi, Gassendi and Dante gives a special character to his pamphlet. The impression that one has reading it is that the author of the Convivio was a free thinker and that the real philosophical and political value of his reflections could not be publicly declaimed as long as the country's reactionary forces reigned sovereign. Dante thus becomes almost a social reformer invalidating all claims to nobility that cannot be substantiated with proof of personal merit, and claiming that man's only potential source of hope is the power of his own mind. Having read this into the Convivio, Poggesi naturally rose against Summo, who represented the traditional view of nobility. But the literary battle that he waged against the sixteenth- 
century critic in defence of Dante was also an academic metaphor for his attack on the philosophical and scientific legitimacy of the aristocracy and for his proclamation of the nobility of intelligence.

\section{DOMENICO PIETROPAOLO}

University of Toronto

\section{Notes}

1 The title is: Lezione accademica in difesa della celebre canzone già composta e comentata da Dante Alighieri su la vera nobilità e nuovamente data in luce (Lucca: Salvatore e Giandomenico Marescandoli 1732). Almost nothing is known of Angelo Poggesi. From the title page of the Lezione we learn that he was a member of the Accademia Fiorentina and a 'dottore,' namely, a university graduate. In the 'Copia dell'approvazione' by the officials of the Accademia Fiorentina it is said that Poggesi is from Pisa (6). Very few of his more famous contemporaries mention his name. Apostolo Zeno, Lettere (Venezia: Valvasense 1753), I, 22, speaks well of him in a letter dated 6 December 1698 and addressed to Antonio Magliabechi, who had first written to Zeno about Poggesi. Zeno had just received a copy of a 'poema' by Poggesi and speaks highly of it. Giovan Mario Crescimbeni, L'Istoria della volgar poesia (Venezia: Lorenzo Basegio 1730-1731), I, 346, says: 'Molto begli anche sono I quattro novissimi e La caccia pisana del dottore Agnolo Poggesi, il primo in terza rima e il secondo in ottava.' The same two works are also mentioned by Francesco Saverio Quadrio, Della storia e della ragione d'ogni poesia (Milano: Francesco Agnelli 1739-1752), VI, 93 and 268, where I quattro novissimi is defined 'un poema sacro'; in volume II, 343, Quadrio cites the volume Rime del dottor Angelo Poggesi (Pisa: 1718). This volume of Rime was briefly reviewed in the Giornale de' letterati d'Italia XXXII (1719) 559, where it is said that it was a new and less complete edition of a previously published anthology. According to the catalogue of the British Museum (s.v. Poggesi), he was a member of Arcadia, wherein he was known as Cidario Orsatto, and contributed a few poems to the third volume of Le rime degli Arcadi (1716). Only I quattro novissimi and La caccia pisana are mentioned in the Biblioteca volante di Gio. Cinelli Colvoli continuata dal dottor Dionigi Andrea Sancassani (Venezia: Albrizzi 1747), IV, 87. Francesco Zaccaria, Storia letteraria d'Italia (Venezia: Poletti 1750), I, 317, recalls him as a friend of Guiseppe Maria Bianchini and says that he was 'uomo di chiara fama per le sue poesie toscane e per altre sue cose stampate.'

2 Cf. for example, Anton maria Salvini, Prose toscane (Venezia: Pasinelli 1734), 300 (Pietro Bembo); Discorsi accademici (Bologna: Nobili 1821), VI, 165-6 (Giovanni Della Casa); Giuseppe Maria Bianchini, Difesa di Dante Alighieri (Firenze: Manni 1718), 11 (Giovanni Pico della Mirandola, Paolo Beni, Pietro Bembo). 
3 See, for example, Michele Barbi, 'Introduzione,' in Il Convivio, ed. G. Busnelli and G. Vandelli (Firenze: Le Monnier 1934; rpt. 1968); LIX.

4 The precise title of the oration is 'Ragionamento della nobiltà altrevolte avuto nell'Accademia degli Animosi in Padova,' published by the author in his Due discorsi, l'uno intorno al contrasto tra il Signor Sperone Speroni et il giudicio stampato contra la sua tragedia di Canace e Macareo, et l'altro della nobiltà (Padova: Paolo Meietti 1590) 41-72. Although Summo's view of the Convivio has engendered no criticism, his ideas on the theatre have been studied by M. T. Herrick, Tragicomedy (Urbana: University of Illinois Press 1962; first edition, 1955) 103-5, and by Bernard Weinberg, A History of Literary Criticism in the Italian Renaissance (Chicago and London: University of Chicago Press 1961; Midwat reprint, 1974), II 945-8.

5 In Politics 1294 a 21 Aristotle defines nobility as a quality of those who possess virtue and ancient wealth, a definition quoted by Dante in De monarchia II, III, 4. In passage 1283 a 37 Aristotle states that nobility is excellence of race. This idea was developed by the ancient philosopher in a lost dialogue on nobility, fragments of which were preserved by Joannes Stobaeus; these may be read in Aristotle's Works, translated into English under the editorship of Sir David Ross (Oxford: Clarendon 1952), XII, where they have been published with the title 'On Good Birth,' pp. 59-62. The fragments include quotations from other ancient writers who mention Aristotle's dialogue, among which is Plutarch, who questions its authenticity. In one of the fragments, nobility (or good birth) is clearly defined as 'excellence of stock' (60).

6 'Vili, imperfetti, paurosi, solleciti, inquieti, insaziabili' (12)

7 'Non semplici pungenti parole, ma un tagliente coltello' (14)

8 'Un'antica virtú di schiatta' (16)

9 De generatione animalium 729 a 22, 783 b $20 \mathrm{ff}$. See also T. S. Hall, History of General Physiology (Chicago and London: The University of Chicago Press 1975), 113-16.

10 Summa theologica I, q. 119, art. 1, resp. 2. See also F.H. Kantarowicz, The King's Two Bodies (Princeton, NJ: Princeton University Press 1957) 332 and n. 61

11 On these ideas, see Gianni Micheli, 'Sviluppo delle scienze reali nel XVII secolo: fisica, chimica, biologia,' in Storia del pensiero filosofico e scientifico, ed. L. Geymonat (Milano: Garzanti 1970), II 538-40; David Jaravsky, 'Inheritance of Acquired Characteristics,' in Dictionary of the History of Ideas, II sub voce. A few representative texts by Francesco Redi (1626-1698), Antonio Vallisnieri (1661-1730) and the later biologist Lazzaro Spallanzani (1729-1799), illustrating the evolution of the concept of reproduction in the seventeenth and eighteenth centuries in Italy, have been recently published with the title La scuola galileana e l'origine della vita, ed. Paolo Cristofolini (Torino: Loescher 1974). The editor of this anthology succintly delineates the terms of reference of the debate in his Nota conclusiva,' 197-9.

12 'Che da niuno dei professori della sua Università di Pisa si legga, né insegni pubblicamente né privatamente, in scritto o in voce, la filosofia democratica, ovvero degli atomi, ma solo l'aristotelica' (emphasis mine). The document is quoted in full by Niccolò Rodolico, Stato e chiesa in Toscana durante la reggenza lorenese: 
1737-1765 (Firenze: Le Monnier 1910; reprint, 1972) 3. On Cosimo's restriction of academic freedom at the University of Pisa see also J. R. Hale, Florence and the Medici: The Pattern of Control (London: Thames and Hudson 1977) 187; Harold Acton, The Last Medici (London: Metheun and Co. Ltd. 1958; first edition, 1932) 192

13 On Giangastone's policies see Rodolico, 14-15; Hale, 191; Eric Cochrane, Florence in the Forgotten Centuries (Chicago and London: University of Chicago Press 1973) 372.

14 The authors that Poggesi cites in support of his thesis include Vives (8), Horace (8), Ovid (8), Juvenal (8), Boileau (20), and Boccaccio (33).

$15 \mathrm{Cf}$., for example, the following passage: $E$ qui attentamente ascoltino e senno insieme apprendano i millantatori di nobiltà che di schiatta essi dicono e gentilesca appellano, d'altro non gloriandosi che dell'eroiche geste de' chiari loro maggiori...e privi in tutto di quell'eccellenze che sono proprie di nobiltà: eh non diansi a credere questi infelici, che per trarre essi l'origine di antica illustrissima schiatta possano dire baldanzosamente noi siam con essa, se le virtú, che sono i propri frutti di nobiltà, germogliare da loro non si veggiono' (32).

16 'Nel seno d'onesta donna' (35)

17 Non è altro che un vivo lume d'intelligenza'(35)

18 Hale observes that, in his attempts to induce his subjects to live in accordance with a strict moral code, Cosimo III went as far as publishing an edict 'forbidding men to enter houses where there were unmarried girls' (196). For the very harsh laws against prostitutes, which date back to a period before Cosimo's accession, see Gaetano Imbert Seicento fiorentino (Milano: Edizioni Athena 1930; first edition, Firenze: Bemporad 1906) 266-78.

19 Acton, 306; Bernard Rochot, 'Chronologie de la vie et des ouvrages de Pierre Gassendi,' in Pierre Gassendi: Sa vie et son œuvre, ed. B. Rochot et al, (Paris: Albin Michel, 1955) 191. On Gassendi's anti-Aristotelianism, which includes a rejection of scholasticism and Aristotle's concept of science, see Tullio Gregory, 'Pierre Gassendi,' in Grande antologia filosofica, ed, M. F. Sciacca and M. Schiavone (Milano: Marzorati 1973) XII, 724-5; Gassendi's anti-Cartesianism is discussed on pages 726-9.

20 Actually Gassendi distinguishes in the soul an anima - which is irrational, corporeal, diffused throughout the body, and is generated by the parents - and an animus, which is the incorporeal rational soul created by God. On this point see G. S. Brett, The Philosophy of Gassendi (London: Macmillan 1908) 112-15; P.-Félix Thomas, La philosophie de Gassendi (New York: Burt Franklin 1967; first edition, Paris: 1889) 225-6.

21 'producono a noi, quantunque posti in questa bassa valle di miserie e di pianto, la terrena felicità' (29)

22 Given the fact that the De monarchia was still a forbidden book, one might expect Poggesi not to make any references to passage II, iii, 4-7, in which Dante accepts the Aristotelian definition of nobility. But he should have mentioned Paradiso XVI, 1-9, where Dante says about nobility of stock: 'nel cielo io me ne gloriai' (v. 6). Poggesi's readers would have probably been familiar with this passage, given the widespread knowledge of the Commedia in Tuscuny. It is fur- 
thermore in order to observe that even in the Convivio Dante admits that in nobility there is an inherited factor which is independent of the individual's will, since God grants the 'seme di felicitade' only to those with l'anima ben posta, cioè lo cui corpo è d'ogni parte disposto perfettamente' (IV, xx, 9). And because certain features, physical and spiritual, are inherited from one's parents, heredity also plays a role in the acquisition of nobility. Nicola Zingarelli, 'La nobiltà di Dante,' Nuova antologia 332 (1927) 412, stresses this aspect of Dante's thought: 'Se sono questi gli elementi della nobiltà, vi ha la sua parte grandissima l'eredità naturale, la nascita; non solo in quanto la virtú del genitore concorre a darla al figlio, ma perché questi a sua volta la darà al figlio proprio. La nobiltà di sangue Dante non la nega.' 